\title{
INNOVATION MANAGEMENT IN THE HIGHER EDUCATION \\ SYSTEM WITH INTEGRATION OF ISO 9000 FAMILY \\ OF INTERNATIONAL STANDARDS AND INTERNATIONAL \\ STANDARDS IN THE FIELD OF ARCHIVAL ACTIVITY, RECORDS MANAGEMENT
}

\section{Bilushchak Tetiana ${ }^{1}$ \\ Myna Zhanna ${ }^{2}$}

DOI: http://dx.doi.org/10.30525/978-9934-571-26-8_1

Abstract. A higher education institution, as a social institution, is responsible for the quality of educational services. Ukraine is on the path to reforming the educational sector. It is important to envisage fundamental changes not only in the structure and content of education, but also in improving the system of a higher educational institution management.

The purpose of this article is to show innovations in the education management system with the integration of ISO 9000 family of international standards and international standards in the field of archival activity, records management.

The methodological basis of the research form the principles of scientificity, systematicity and objectivity. The general scientific methods (of analysis, synthesis, comparative, systematization, generalization) have been used when writing the paper. The material has been presented according to the thematic principle. Comparative, typological and functional methods have been used for a comprehensive research of the topic.

The subject of the study is the introduction of innovative management in higher school on the basis of ISO 900 family of international standards and international standards in the field of archival activity, records management.

The paper stresses that we need to direct the activity of higher educational establishments in accordance with quality standards, to motivate the faculty staff to innovative professional activities, to apply up-to-date methods of educational management, to competently communicate with subjects

\footnotetext{
${ }^{1}$ Ph.D., Assistant Lecturer of Social Communication and Information Activities Department, Lviv Polytechnic National University, Ukraine

${ }^{2} \mathrm{Ph} . \mathrm{D}$., Senior Lecturer of Social Communication and Information Activities Department, Lviv Polytechnic National University, Ukraine

(C) Bilushchak Tetiana, Myna Zhanna
} 
and objects of management. The relevance of professional growth, skills and competencies of the manager, as well as skills to stimulate creative and search activities have been emphasized. Thus, the authors of the article suggest that innovation management in education is an art of management. The modern manager is, before everything else, an effective innovative leader with systemic fresh thinking on the issues of internal communication, has high human qualities, is able to carry out marketing research and forecast the development of events. It follows therefrom that in the process of innovation management with the integration of ISO 9000 family of international standards and international standards in the field of archival activity, records management, the higher education manager consistently and purposefully introduces new technologies for business career management, and thus provides for optimal and effective activity of higher education institution. The article shows that innovation management in education creates an edu-cational environment that functions efficiently and meets the current dictates of times, and is also attractive (and this is extremely important today) for the potential consumer of educational services. While proving their postulates, the authors of the paper, show that it is absolutely impossible to manage education today, if not all its components are considered - innovative methodological base, personnel, pedagogical management, finance, the process of studying through the interaction of disciplines, well-established document communication (since any process, means of information sharing, making managerial decisions is impossible without being recorded on paper or electronic media). It has been suggested to use the state standards to manage document processes the Lviv Polytechnic National University. These standards were modified on the basis of international ones, such as DSTU 4423-1:2005 "Information and documentation. Records management. Part 1: Key provisions (ISO 15489-1: 2001, MOD) and DSTU 4423-2:2005 "Information and documentation. Records management. Part 2: Guidelines (ISO/TR 15489-2:2001, MOD). Documentation management is considered in the international standard as a part of the quality management system based on the requirements of ISO 9001 (Quality Management System).

Thus, innovation management in the higher education system with integration of ISO 9000 family of standards and international standards in the field of archival activity, records management provides for the provision of qualitative content of educational programs and qualifications of 
the academic staff, effectiveness and efficiency of joint efforts of the staff, determination of incentives and development of the performance evaluation system, development of the personnel policy, personal responsibility, creation of conditions for fruitful work, effective use of resources, formation of records management on the basis of standards, creation of an efficient information retrieval archival system.

\section{Introduction}

Relevance of the topic. The established methods that provide high quality of studies require a thorough analysis and review today. The essence and methods of modern higher education should contribute, first of all, to the disclosure of creative potential of an individual. The strategy for the development of higher education should become the impetus for Ukraine's economic growth. These goals can only be realized, of course, if advanced information technologies are implemented.

A graduate must be competitive in the globalized labor market. Therefore, education should be innovative. The graduate must be ready to "challenges of time" and be free to make decisions in a changing environment of various factors, using knowledge and skills he/she gained, quickly adapt to scientific and technical progress. Therefore, the quality of education in a broad sense has to be decisive and provide the necessary level of training of specialists, capable of effective professional activities. What is more, we should not forget that higher education will be of higher quality and more perfect, and will contribute to personal development in the humanistic approach. This is extremely important. Ethical principles, and actually environmental ones, should be of top priority.

A higher education institution, using a variety of organizational, methodological, and technological factors, must have an effective management system of future specialists training. M.M. Levshyn, S.A. Svizhevska emphasize that "One of the significant obstacles to wide introduction of quality management systems in higher education institutions of Ukraine is the lack of theoretical and practical developments in this area. Consequently, unlike foreign practice, where the introduction of quality management systems at universities is quite common, only some universities in Ukraine begin addressing this issue" [6, p. 50]. Hence, therefrom follows the urgency of creating innovative foundations for the development of quality management systems of higher education institutions based on the prin- 
ciples of general quality management and the requirements of international standards of ISO 9000 family.

The purpose of the article is to analyze the innovations of educational man-agement and strengthen the competitive positions in the European educational market through the integration of international standards of innovation management, records management and in the field of archival activity.

Tasks required to achieve the goal: to conduct an analytical review of scien-tific papers describing the materials of application of ISO 9000 family of international standards; to show the importance and expediency of innovations in the education management system with the integration of international standards of ISO 9000 family and international standards in the field of archival activity, records management, to analyze ISO 9000 family of international standards and international standards in the field of archival activity, records management to make suggestions for improvement of functioning of the Lviv Polytechnic National University; to determine the expediency and make suggestions based on the standards on automation of the archival unit operation and records management at the Lviv Polytechnic National University.

Research methods. The methodological basis of the research form the principles of scientificity, systematicity and objectivity. The general scientific methods (of analysis, synthesis, comparative, systematization, generalization) have been used while writing the paper. The material has been presented according to the thematic principle. Comparative, typological and functional methods have been used for a comprehensive research of the topic.

The theoretical and practical results of implementing the standards of records management and in the field of archival activity have been studied using the methods of analysis and synthesis.

The method of analysis has been used for a detailed study of standards applied in records management and in the field of archival activity, which made it possible, in particular, to study scientific viewpoints on the need for implementation. The method of synthesis made it possible to distinguish the types and the system of standards of records management and in the field of archival activity.

Analysis of sources. In addition to the aforementioned authors, the following domestic scientists deal with the issue of creating theoretical, meth- 
odological, regulatory and informational principles for the development of quality management systems of higher education institutions on the basis of principles of general quality management and requirements of international ISO 9000:2000 standards: T. Finikov, S. Laptiev, L. Vitkin, S. Piddubna, H. Khimicheva, K. Metashkin, O. Volkov, M. Shapoval. Thus, L. Vitkin, S. Laptiev, T. Finikov, S. Piddubna considered the main principles and approaches of modern quality management in the manual "Development of Quality Management System of Higher Education Institutions". The recommendations for the development of implementation and support of the quality management system in higher education institutions have been provided. A number of innovations in the field of quality of higher education have been suggested.

The issues of standardization development in the field of archival activity and records management are the subject of analysis of many scientists, both Ukrainian and foreign ones. In the publications of such Ukrainian scholars as I. Antonenko, V. Bezdrabko, H. Bespianska, L. Greenberg, V. Dobrovolska, L. Drahomirova, O. Zahoretska, L. Kyseliova, M. Komova, S. Lytvynska, P. Marchenko, I. Matiash, O. Tur, S. Kharchenko, N. Khrystova, A. Shurubura, et al., a wide range of issues related to the creation and functioning of standards in this area have been raised. However, there are not enough generalizing works today elaborating on the issues of introduction of innovation management in the system of higher education institutions with the integration of ISO 9000 international standards and the use of standards with the help of automation of the archival unit operation and records management in higher education institutions taking into account its specificity.

\section{The main tasks of innovation management in the system of higher education}

Analyzing innovation management in the system of domestic higher education using ISO international quality standards, we cannot but mention the principles of Edward Deming, which are and remain relevant due to their universality. By following these principles, one firstly needs to understand that awareness of the goals and their successful attaining is important. You need a clear action plan and a developed action strategy to achieve the goals. The main means to achieve the goals and the key function of management should be the quality management in higher education. Employees of higher education institutions need to keep up with the times and accept 
challenges, first of all, the challenges of quality improvement. Let us pay the attention to the third Deming's principle - the quality audit since it is too important. And here it is not about looking for drawbacks in work, but understanding the audit as being aimed at improving the processes in educational activities and search for the right decisions. All work should be aimed at ensuring initial quality, and this principle must be followed at all stages of work. At the same time, it is necessary to continuously improve your pedagogical and scientific excellence.

Today, the competition for quantitative indicators in scientific and pedagogical activity is a big problem. There should be effective competition instead, aimed at quality, but not quantitative indicators. At the same time, experiments, innovative ideas, creative approaches with every possible support of leadership should be supported in every possible way. The managers' task is to develop methods for improving quality. It is important to develop educational programs, programs of retraining and advanced training, attracting leading specialists.

The task of managers is to develop methods for improving quality. Problems should grow into tasks, creative solutions, quality changes in education should be welcomed, break the innovative level of development. Consultations and organizational assistance in searching for and making tricky decisions should influence the improvement of quality of educational process. What is important is the ability to find compromise solutions, prompt resolution of all existing problems, analytical forecasting; feedback; promising outlook; attention to personnel; legal priority and legality; financial and economic rationality. The theoretical understanding and practical application of the latest achievements of international management (up-to-date principles, methods, techniques, strategies, structures, controlling mechanism at the level of international standards) is extremely important because it will facilitate rapid accession into the global economic community as an equal partner.

The experience of introducing QMS in higher education institutions points to its advantages, namely:

- improving labor efficiency;

- cost optimization;

- improving the quality of training of future specialists;

- foreign cooperation, participation in tenders for conducting research work; 
- certification and recognition procedure in the domestic and foreign markets.

By analyzing the content of DSTU ISO 9001:2000 [4] standard in accordance with its application at universities, the authors of the manual "Development of Quality Management System of Higher Education Institutions" [3, p. 179] suggest the following model of QMS of the higher education institution, which serves as a guideline (fig. 1).

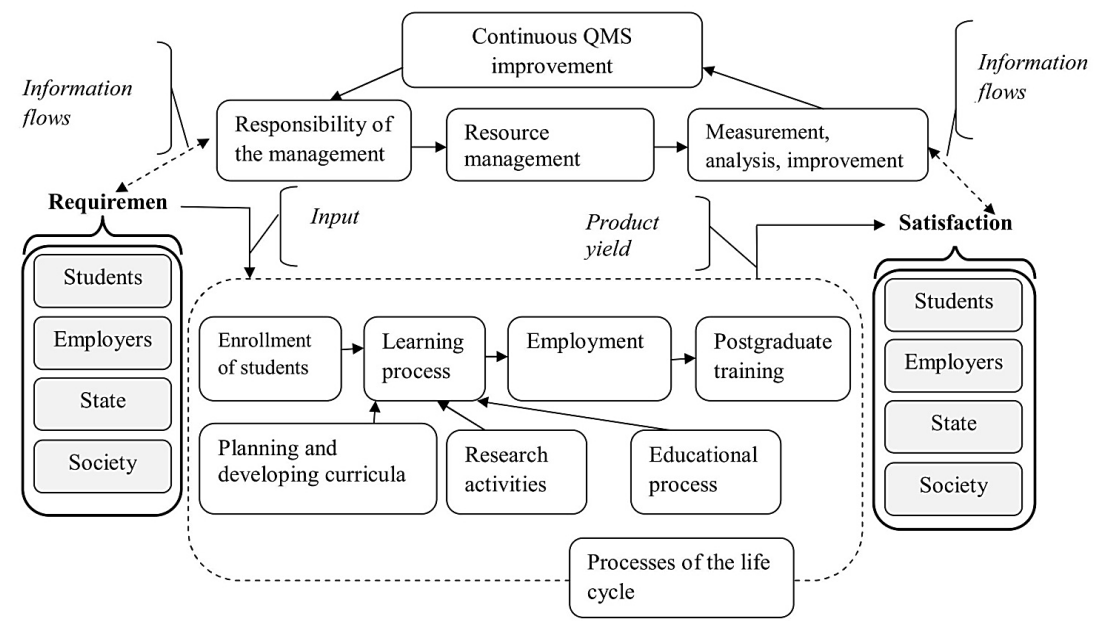

Fig. 1. QMS model in Universities

It is proposed to apply an algorithm of the university activity, comprising: identifying a certain system of processes necessary for quality management, defining relationships, cooperation, consistency in the system of processes, identifying key processes from the perspective of strategic plans and objectives; searching for an employee ready to take responsibility for the process, giving him adequate powers, i.e. appointment of the process owner; determination of the process customer or consumer and description of the process outputs, that is, the requirements for the quality of the results of its functioning; determination of the process suppliers and requirements for input elements of the process, that is, resources; determination of the criteria for effective management of this process and selection of methodological support for measurements of these criteria; planning processes of quality and effective process indicators measurement; description of the 
process as a flowchart with the account of the process management system; determination of outgoing and incoming documents according to the stages of the process; provision of information flows necessary for effective process management and monitoring; conducting regular monitoring and analysis of data relating to the process; systematic implementation of corrective and preventive actions aimed at attainment of the process goals; determination of the procedure for making changes in the process [3, p. 179].

In turn, university's management, in accordance with the proposed model, should provide the necessary resources. First of all, these are human resources (faculty and other staff). What is more - premises, equipment (laboratories, computer network, library stock, compliance with sanitary and technical standards, etc.) [3, p. 179].

Thus, the high quality of the university activities as a whole will determine both the improvement of the very processes and the system in general through the effective management of each key process and through their interaction. In this case, management should be carried out through the control of the indicators that characterize them.

It should be emphasized that DSTU ISO 9001-2001. Quality management systems. Requirements and DSTU ISO 9004-2001. Quality management systems. Guidelines for performance improvements act as compatible with each other. The second of these standards is rather broad and goes beyond the requirements of the first one. Therefore, it is recommended to use the second standard as well for the higher education institution, where the quality management system is implemented in accordance with the requirements of the first standard in order to maintain efficiency and ensure further improvement.

\section{Analytical abilities of the education manager}

The education manager carries out continuous analysis and processing of information and makes the corresponding decisions on that basis. Therefore, he/she must have analytical skills. It is important to make realistic forecasts based on a comprehensive analysis of real situations and the construction of specific models of functioning of pedagogical process or the educational institution in general. Therefore, helshe must possess such business qualities as professional skills; initiativity; good organization (rational use of time, workplace arrangement); responsibility; diplomacy, ability to maintain professional secrecy (use only actual, strictly verified information, 
not to disclose secret information, as well as information that is truthful, but may harm the organization or individual employees if disclosed; keep documents properly).

Analytical forecasting is carried out on the basis of processing of information about personnel, financial and economic, as well as material and technical capabilities of the educational institution, the psychology of performers, stereotypes of their thinking in solving the matters of principal, about deadlines, ways of adjusting and criteria for the quality of actions and tasks performance. The "access mode" term is used to define legal aspects $[7$, p. 22].

\section{Responsibility of the higher education institution management and factors influencing the quality of training in comparison with TQM principles, EFQM criteria and requirements of the international ISO 9001 standard}

Analyzing the content of DSTU ISO 9001-2001 standard. Quality management systems. Requirements and the issues of innovation management, we will consider section 5 "Responsibility of management". Senior management, being in charge of the work on the QMS implementation, should organize work based on the strategic plan. The medium-term development plan is suggested for 3-5 years and the long-term one - for 7-10 years.

There should be a quality coordination council. The Department for ensuring functioning of the quality management system functions at the Lviv Polytechnic National University. The main tasks of the Department for implementing the University's quality assurance policy of educational services is the practical implementation of the plan for QMS implementation at the University, the development of proposals, draft documents for the rector and the Academic Council to improve the regulatory framework of the organization of the educational-bringing-up process and the University's quality management system. Moreover, participation in the development and improvement of the following techniques: rating assignment to the University chairs; rating assessment of the activities of academic staff of the University; monitoring the quality of University's specialists training, etc. The main tasks also include the collection, analysis and generalization of information on the quality of educational services at the University.

Inspections of the organization of educational-bringing-up process and the state of affairs in the structural subdivisions of the University took place 
under a separate rector's order. The tasks also include the analysis of performance and results of students training and the work of the State Examination Commissions; checking the chairs' readiness for the new academic year; analysis of the results of the rating assessment of performance of academic employees of the University; planning and registration of methodological editions of the University and issuance of quality certificates; organization of control of residual knowledge of students; organization of works on rating of the university chairs; organization of work on conducting the first and the second rounds of All-Ukrainian student competitions and competitions of qualifying papers, collecting and processing reports on the results of their conduct.

The state and improvement of the QMS should be regularly considered at the Academic Council of higher education institutions, academic councils of the institutes (faculties), meetings of the chairs. Materials about the quality of student training, consumer feedback (students, employers, NGOs, representatives of governmental bodies) should be disseminated through the internal computer network of the university and its printed media [3, p. 184].

The list of factors, presented in Figure 2, that influence the quality of training in comparison with TQM principles (Total Quality Management), EFQM criteria (European Foundation for Quality Management) and the requirements of the international ISO 9001 standard (International Organization for Standardization) [6, p.53] gives grounds to conclude that these factors are fully integrated into the common TQM ideology, which they are based on.

Creation of scientifically grounded methodological approaches to assessing the quality of students training, the universities' performance, development, implementation and monitoring of a professionally oriented quality management system (QMS) of higher educational establishments, its regulatory and computer support require the development of a conceptual model of the quality of university students' training based on TQM principles, and derivation of the formula for assessing the university's performance; construction of the QMS model of the higher education institution and monitoring system using a process approach; studying the impact of the quality of students' training on the competitiveness of universities, in particular, the multifactor model of student admission and the model of academic progress; development of recommendations on the implementation 


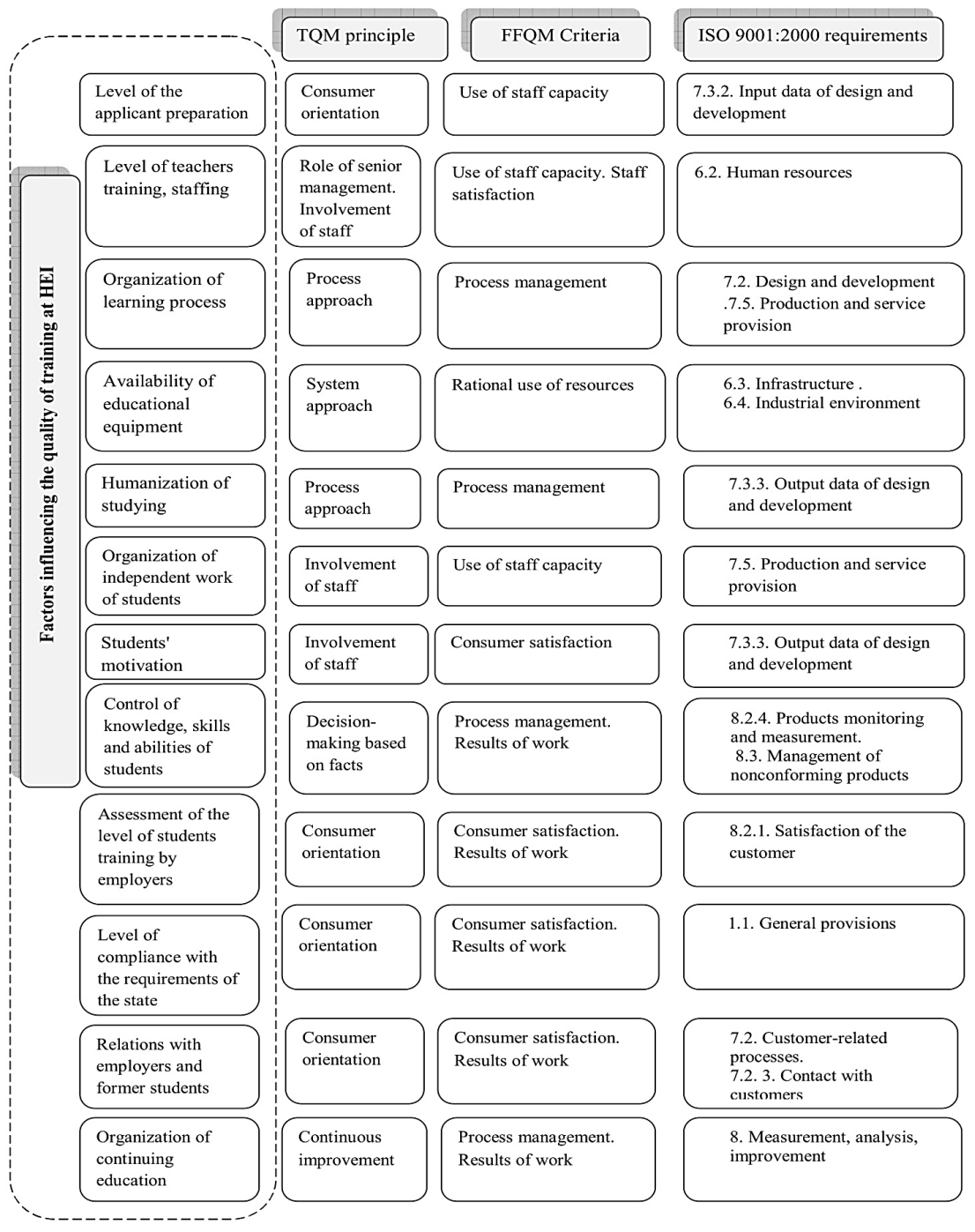

Fig. 2. A comparative table of the list of factors influencing the quality of training in comparison with TQM principles, EFQM criteria and the requirements of the international ISO 9001 standard 
of QMS of higher education institutions using the methodology of project management; application of the method of the quality function structuring for the development of a set of regulatory documents of higher education institution QMS; development of the modular process-oriented information system for the maintenance of the University's QMS with the use of programming and databases; approbation of the created documentation, methodological and program developments on the basis of selected universities $[6$, p. 53].

\section{Improvement of functioning of the electronic document flow system in accordance with the requirements of state standards}

The development and existence of society depends on social and communicative activities. The social communication channel is provided through document communication. That is, any processes, mediums of exchange, and adoption of managerial decisions is impossible without being recorded on a paper or electronic medium. Taking into account the prospects of Ukraine's activities in the European collaboration market, development of the documentation field requires consideration of the world's practical experience and integration of international standardization and unification of information processes.

Ukrainian higher education institutions (HEIs) should work to not only provide high-quality content of educational programs and qualifications of the faculty staff, but also pay attention to the formation of standards-based documentation management for successful work and cooperation with European educational institutions [2, p. 27; 5, p. 31].

A set of international standards on compliance with harmonization in Ukraine in the field of archival activity and records management will allow organizing work with document information in an educational institution in a more efficient way. In records management at the Lviv Polytechnic National University it is suggested using state standards, which were modified on the basis of such international standards as DSTU 4423-1:2005 "Information and documentation. Records management. Part 1: Key provisions (ISO 15489-1: 2001, MOD) [9] and DSTU 4423-2:2005 "Information and documentation. Records management. Part 2: Guidelines (ISO/TR 15489-2:2001, MOD) [10]. The international standard considers the documentation management as a part of quality management system based on the requirements of ISO 9001 standard (Quality Management System). The 
national version of DSTU 4423: 2005, which has been modified on the basis of the international standard ISO 15489, includes recommendations for an optimal records management methodology, which is intended for experts in the field of document management, and experts in other fields of activity. In particular, this standard can be used by developers of new information programs and systems to ensure compliance of these programs and systems with the requirements for records management.

The standard deals with the management of documents of all kinds and on all carriers created or received by an organization in the course of its activities, as well as by individuals who must create and use documents.

There is a department at the Lviv Polytechnic National University for implementation and maintenance of electronic document flow systems, which uses the document flow management system of modern ECM and BPM solution base on Alfresco platform. The following criteria became decisive in selection of this system functioning at the University: open source; state-of-the-art technological solutions; support of the most common file formats; advanced possibilities of business process modeling; multilevel system for access control to information [8, p. 192].

According to section "Documentation processes and their control" of DSTU 4423-2:2005 "Information and documentation. Records management. Part 2: Guidelines" to make Alfresco system function effectively, it should be based on these advisory requirements. According to the standard, it is suggested to include service documents in the electronic documentation system that require configuration, which would remind of filling out the fields necessary for metadata, or a configuration that would automatically create such metadata.

We also offer to improve the classification of areas of business activities in accordance with the standard. A system of classification associated with business functions can provide a systematized structure for records management. The fully developed form of classification reflects the functions, areas of activity and operations of the higher education institution. Such reflection can be used to develop a scheme for classification of service documents and thesaurus, rules for providing headings to documents and their indexing, determining the deadlines for storage of documents and classification of access at higher education institution. Such a classification system will give a tool to the Lviv Polytechnic National University to organize, describe and logically combine its service documents; com- 
bine and divide interdisciplinary documents, both internal and external for an organization, and, if necessary, provide improved access, search, use and classification of their service records. Supported by such tools as vocabulary control, the classification system ensures unification in providing headings to service documents and their descriptions, which facilitates searching for and using service documents. The scheme of classification of the areas of activity of the institution can be developed using the methodology described in section "Strategy, development and implementation" based on stage A "Preliminary study" and stage B "Business activity analysis".

The developer of the classification systems should observe the following provisions:

a) Vocabulary of the system should be based on its business functions and areas of activity, and not on the names of the organization divisions;

b) The systems are specific to each organization and provide a consistent and standardized way of communication across organizational units using the same information to perform interrelated functions;

c) They are hierarchical, they should proceed from the most general to the most specific concept, that is, from the general function to the specific action;

d) They contain precise terms used in the organization;

e) They contain large groups and subgroups that cover all business functions and areas of activities to be documented;

f) They contain separate groups;

g) They are developed in consultation with the authors of service documents;

h) They reflect changes that are made to ensure that the scheme meets up-to-date requirements and reflects changes in the functions and areas of activities of the organization [10, p. 9].

The most effective way to determine, which service documents should be attached to the documentation systems and how long they should be stored, is when it is systematically done in accordance with the laws and instructions. The means for making such decisions may include instructions identifying service records to be destroyed or included in the documentation system, formally accepted lists of classes of documents, storage periods and appropriate actions on transfer of service records to the archive or their withdrawal for destruction, which are subject to approval by the 
external competent authority - the file register. In electronic documentation systems, documents attaching and storing is considered at the initial stage of system development.

Service documents are added to the electronic documentation systems as a result of a well-developed process, which is a registration according to its tasks and objectives. Information about the people involved in the operation, the activities performed and the service records that are the result of this activity, can be recorded with varying degrees of specification. The level of required specification depends on the needs of the activity and the scope of use of the service document. Example:

a) service records with respect to one person can be grouped into simple systems using the minimum search-based information, in particular, into such systems as personal, referential case file with copies of instructions and laws;

b) service records that are never used outside of one unit require documentation of details only that are sufficiently understandable within the unit;

c) service records that go beyond a particular unit require more information that identifies this unit and the involved performance in the context of the entire organization activity;

d) service records created in the public domain, such as World Wide Web, require more information in accordance with the context, since it can be predicted that users will consider a document with a different understanding of operations in the context of which it was created [10, p. 21].

\section{Automation of archival activity on the basis of integration of international standards}

One of the main structures of the system of social communication is archives, including archives of structural units of HEIs. One of the first and priority tasks of the archives of structural subdivisions of universities is not only the storage of documents, but also the active use of archival information in solving socially important tasks - verification of personal data. Strengthening the requirements for the level of informatization and dissemination of the processes of European integration determine the leading role of the HEI's archival units, which ensure the implementation of state policy in the archival sector, organize the formation and storage of information resources. 
The main tasks of the university archive as a subject of educational activity are the organization of the records use, issuance of archival certificates, copies, extracts to legal entities and citizens in accordance with the established procedure, creation and improvement of the reference tool for access to archival documents. One of the problems of the archive functioning of the structural unit of Lviv Polytechnic National University is a large number of information queries daily, which is about 100 . Since the search for information is carried out through paper media, which significantly complicates and slows down the work of the employee, it is proposed to change the manual search technology for electronic one using the information retrieval system.

In order to establish common requirements for the definition of the quality of service provision, enterprises, institutions, local governments, archival information, extracts and copies to fulfill the biographical and factual requests by the archival departments of the higher educational institutions are implementing a management system quality. The regulatory framework for the creation of such systems is the international standard ISO 9001-2008, "Quality Management Systems" [4]. The process of providing archival references, excerpts, copies includes:

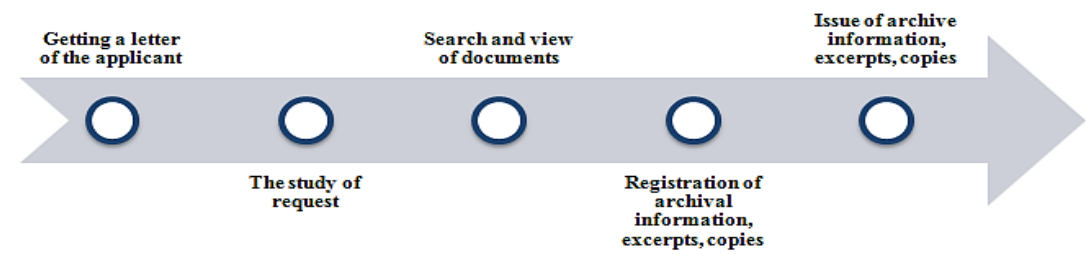

The prerogative of the information retrieval archive system is that it enriches the prospects for the user in the work of an array of archival information as a means of using the relevant databases in the structural department of the university, which allows only limited access to documents. Thus, the information retrieval archive system will allow:

- to search for a person (surname, name, last name, year of birth or period of work and study), regardless of place of his stay in the past,

- search for a person in all documents,

- search for object,

- to organize the geographical and chronological filter of documents;

- automatic filling of the template of the document for extraction from the archive. 
Information search system in (ISS) the form of a database is created:

1. In order to improve the conditions of citizens' servicing;

2. Improving the efficiency of work is the speed of service, the convenience of finding information, eliminating barriers to obtaining services through a human factor (corruption, bureaucracy, physical overload, etc.);

3. Storing of archival documents.

In order to organize the activities of the colleges of higher educational institutions, it is necessary to adapt the ISS to the needs of the archival industry in accordance with the international standard ISAD (G): 1999 "General international standard archival description". Consider the construction of an ISS conforming to the international standard ISAD $(\mathrm{G})$. The elements of the description of the document must contain the following blocks, which are shown in Fig. 3.

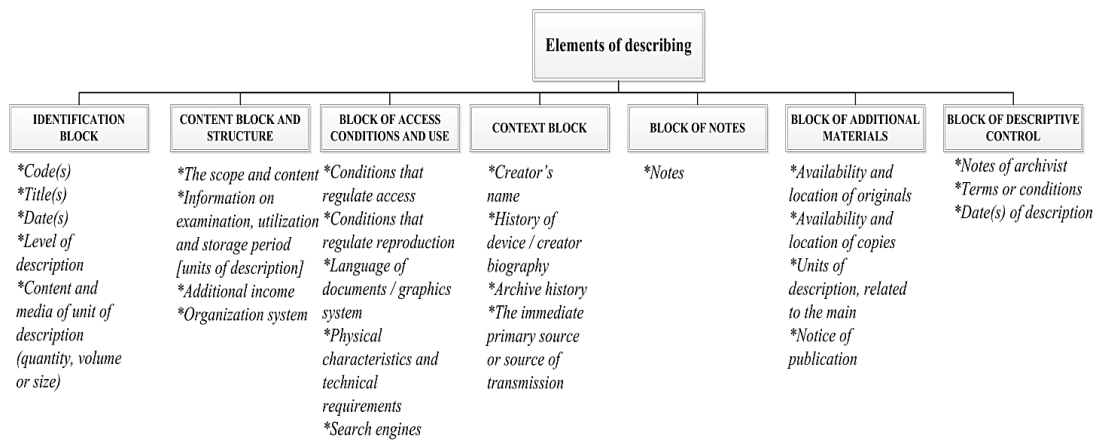

Fig. 3. Schematic representation of the elements of the description according to the international standard ISAD (G): 1999 and their blocks.

The development of an information retrieval system facilitates the laborious and routine work of the search problem and will be implemented as a means of reliable data storage, which makes it convenient and quick to find the necessary information [1, p. 202]. It is also proposed for the final stage of processing the results of the request for the archival information found to automatically fill this information in a template form in the database for issuing documents (Fig. 4).

Consequently, as a result of the analysis of the problem of finding large volumes of document and information arrays in the archive department of higher educational institutions, the Lviv Polytechnic National University it 
was proposed to implement an information retrieval system in the form of a database.

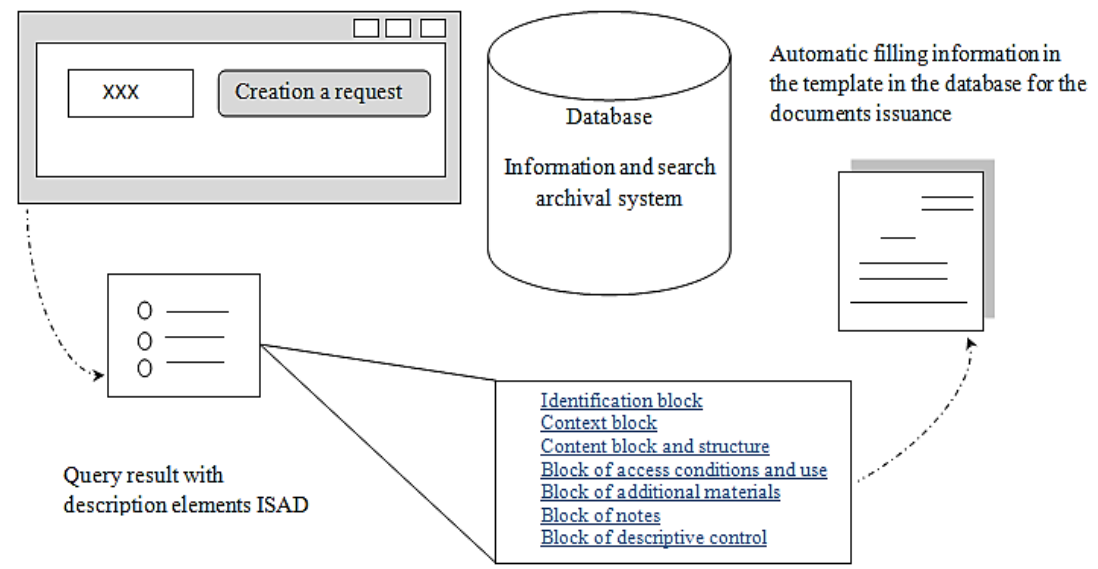

\section{Fig. 4. Schematic representation of the execution of the request in the Archival Information Retrieval System}

This search archival system must conform to the International Standard for Archival Descriptions ISAD (G). Thus, the information retrieval archive system, which is able to accumulate information and outputs of it on multidimensional requests, will allow the employees of the department of higher education to increase the efficiency of the implementation of requests for verification of personal data of graduates and university employees.

\section{Conclusion}

Thus, innovation management in the higher education system with the integration of ISO 9000 family of international standards and international standards in the field of archival activity, records management should include the following components: innovative methodological base, personnel, pedagogical management, finance, the process of studying through the interaction of disciplines, well-established document communication (since any process, means of information sharing, making managerial decisions is impossible without being recorded on paper or electronic media). On the example of records management, namely, the electronic document flow system at the Lviv Polytechnic National University, for successful 
functioning of the system and competitiveness in the European market, it is suggested to make proposals to use state standards that have been modified on the basis of international ones: DSTU 4423-1:2005 "Information and documentation. Records management. Part 1: Key provisions (ISO 15489-1: 2001, MOD) and DSTU 4423-2:2005 "Information and documentation. Records management. Part 2: Guidelines (ISO/TR 15489-2:2001, MOD). Documentation management is considered in the international standard as a part of quality management system based on the requirements of ISO 9001 (Quality Management System). It has been also suggested changing the manual search technology to the electronic one at the Lviv Polytechnic National University's archival unit by using the information retrieval system in the form of a database, which should be designed to comply with the International Standard for Archival Descriptions ISAD (G). The designed information retrieval archival system, taking into account the international standard of archival description ISAD (G), will allow the archival unit of the Lviv Polytechnic National University to apply international rules and technologies that will be clear to all when entering the European information space.

Innovation management in the higher education system with integration of ISO 9000 family of standards and international standards in the field of archival activity, records management provides for the provision of qualitative content of educational programs and qualifications of the academic staff, effectiveness and efficiency of joint efforts of the staff, determination of incentives and development of the performance evaluation system, development of the personnel policy, personal responsibility, creation of conditions for fruitful work, effective use of resources, formation of records management on the basis of standards, creation of an efficient information retrieval archival system.

\section{References:}

1. Bilushchak T., Myna Zh., Yarka U., Peleshchyshyn O. (2017) Integration processes in the archival section of Lviv Polytechnic National University. Proceedings of the XI' International Scientific and Technical Conference "Computer Sciences and Information Technologies" (Ukraine, Lviv, September 05-08 2017), Lviv: Lviv Polytechnic Publishing House pp. 200-203.

2. Bilushchak T., Komova M., Peleshchyshyn A. (2016) Poniattievoterminolohichnyi aparat keruvannia dokumentatsiinymy protsesamy [Conceptualterminological apparatus for managing documentation processes] Proceedings of the IX Mizhnarodnoho naukovo-teoretychnoho seminaru "Terminolohiia doku- 
mentoznavstva ta sumizhnykh haluzei znan" (Ukraine, Kyiv, June), Kyiv:Chetverta khvylia, pp. 27-33.

3. Vitkin L.M., Laptiev S.M., Finikov T.V. (2009) Pobudova system upravlinnia yakistiu vyshchykh navchalnykh zakladiv [Building quality management systems of higher education institutions]. Kyiv: Taksona. (in Ukrainian).

4. DP NDI "Systema" (2009) Systemy upravlinnia yakistiu. Vymohy: DSTU ISO 9001:2009 (ISO 9001:2008, IDT), Kyiv: Derzhspozhyvstandart Ukrainy.

5. Komova M.V., Peleshchyshyn A.M., Bilushchak T.M. (2013) Keruvannia dokumentatsiinymy protsesamy [Records management]. Lviv: V-vo Lvivskoi politekhniky. (in Ukrainian).

6. Levshyn M.M. Svizhevsjka S.A. (2012) Neobkhidnistj vykorystannja mizhnarodnykh standartiv jakosti ISO u praktyci vyshhykh navchaljnykh zakladiv Ukrajiny. Stan vprovadzhennja innovacijnogho menedzhmentu [The need to use international ISO standards in the practice of higher education institutions in Ukraine. The state of implementation of innovation management in the national system of higher education]. Proceedings of the Upravlinnja jakistju pidghotovky kadriv z vyshhoju osvitoju cherez udoskonalennja procedur licenzuvannja, akredytaciji ta rejtynghuvannja (Ukraine, Dnipropetrovsk, March 15-16, 2012) (eds. Salov V.O., Pysjmenkova T.O., Svizhevsjka S.A., Sobolj V.S), Dnipropetrovsk : Nacionaljnyj ghirnychyj universytet, pp. 50-54.

7. Myna Zh.V. (2016) Analityko-syntetychne opracjuvannja informaciji [Analytical and synthetic processing of information]. Lviv: Publishing House of Lviv Polytechnic. (in Ukrainian).

8. Peleshchyshyn O., Zhezhnych P. (2016) Systema slabostrukturovanoho dokumentoobihu Lvivskoi politekhniky na bazi platformy Alfresco [System of weakly structured workflow of Lviv Polytechnic on the basis of Alfresco platform]. Proceedings of the VIII ${ }^{\text {th }}$ Innovatsiini kompiuterni tekhnolohii $u$ vyshchii shkoli (Ukraine, Lviv, November 22-24, 2016), Lviv: Vydavnytstvo Naukovoho tovarystva im. Shevchenka, pp. 190-194.

9. UNDIASD Derzhkomarkhivu Ukrainy (2007) Informatsiia ta dokumentatsiia. Keruvannia dokumentatsiinymy protsesamy. Ch. 1: Osnovni polozhennia (ISO 15489-1:2001, MOD): ДСТУ 4423-1:2005 [DSTU 4423-1:2005 "Information and documentation. Records management. Part 1: Key provisions (ISO 15489-1: 2001, MOD)], Kyiv: Derzhspozhyvstandart Ukrainy.

10. UNDIASD Derzhkomarkhivu Ukrainy (2007) Informatsiia ta dokumentatsiia. Keruvannia dokumentatsiinymy protsesamy. Ch. 2: Nastanovy (ISO/TR 15489-2:2001, MOD): ДСТУ 4423-2:2005, [DSTU 4423-2:2005 "Information and documentation. Records management. Part 2: Guidelines (ISO/TR 15489-2:2001, MOD)], Kyiv: Derzhspozhyvstandart Ukrainy. 